Book Reviews The Oxford Handbook of the Study of Religion edited by Michael Stausberg and Steven Engler, Oxford University Press, Oxford, 2016, ISBN 978019972957 0; 2019, ISBN 9780198729587

Uehlinger, Christoph

DOI: https://doi.org/10.1080/0048721X.2020.1796421

Posted at the Zurich Open Repository and Archive, University of Zurich

ZORA URL: https://doi.org/10.5167/uzh-188720

Journal Article

Published Version

Originally published at:

Uehlinger, Christoph (2020). Book Reviews The Oxford Handbook of the Study of Religion edited by Michael Stausberg and Steven Engler, Oxford University Press, Oxford, 2016, ISBN 978019972957 0; 2019, ISBN 978019872958 7. Religion, 50(4):725-732.

DOI: https://doi.org/10.1080/0048721X.2020.1796421 


\section{The Oxford Handbook of the Study of Religion}

edited by Michael Stausberg and Steven Engler, Oxford University Press, Oxford, 2016, xviii + 862 pp., US\$150.00 (hardcover), ISBN 978019972957 0; 2019, US\$50.00 (paperback), ISBN 9780198729587

\section{Christoph Uehlinger}

To cite this article: Christoph Uehlinger (2020): The Oxford Handbook of the Study of Religion, Religion, DOI: 10.1080/0048721X.2020.1796421

To link to this article: https://doi.org/10.1080/0048721X.2020.1796421

\section{Published online: 21 Jul 2020.}

Submit your article to this journal $₫$

\section{Щ Article views: 16}

Q View related articles $\sqsubset$ 


\section{BOOK REVIEW}

The Oxford Handbook of the Study of Religion, edited by Michael Stausberg and Steven Engler, Oxford University Press, Oxford, 2016, xviii + 862 pp., US\$150.00 (hardcover), ISBN 978019972957 0; 2019, US\$50.00 (paperback), ISBN 978019 8729587

'Handbook(s) of ...', 'Companion(s) to ...' and similarly titled series and edited volumes, often preceded by the proud mention of a respectable global publishing house, will perhaps be remembered in a few decades as one of the early 21 st century's most conspicuous genres in academic publishing. ${ }^{1}$ Intellectually speaking, the genre of single-volume handbooks (not to be confused with long-standing projects such as the Handbook of Oriental Studies) seems to betray a pressing need perceived by committed academics to constitute isles of substantive reference and convenient orientation in an inexorably warming sea of limitless digital information of often rather unsecure status. ${ }^{2}$ Their place is on the bookshelf (or digital archive) of public and research libraries, where they offer a reasonably representative selection of views about any given topic, or on the desk (or memory disk) of professors and lecturers whose job requires that they teach topical courses or overviews which sometimes reach far beyond their individual expertise and personal comfort zone. This said, I doubt whether interested readership constitutes the genre's main pull-factor. What is it then that motivates scholars and academics, dozens of deserving editors and hundreds of complacent contributors, to edit and write for handbooks, considering the fact that, despite publishers' promise to the contrary, original research will rarely be looked for (nor actually found) in books of that kind?

According to the publisher's advertising, the purpose of 'Oxford Handbooks' is to

offer authoritative and up-to-date surveys of original research in a particular subject area. Specially commissioned essays from leading figures in the discipline give critical examinations of the progress and direction of debates, as well as a foundation for future research. Oxford Handbooks provide scholars and graduate students with compelling new perspectives upon a wide range of subjects in the humanities, social sciences, and sciences. ${ }^{3}$

So, how is the promise about the 'series', to which the editors of the volume under review explicitly refer in their very brief introduction (1), fulfilled in The Oxford Handbook of the Study of Religion (henceforth: OHSR)?

To review a handbook is not an easy task, which may explain why to my knowledge OHSR has got relatively few echoes since its publication in late 2016 (some may still be on their way, though, and a collaborative product of no less than 56 contributors excludes per se a significant number of potential reviewers). ${ }^{4}$ In this review, I (1) briefly characterize the volume's list of

\footnotetext{
${ }^{1}$ For reasons of space limitation, this review article had to be considerably shortened during the process of editing. A fuller version may be found on the reviewer's Academia page.

${ }^{2}$ In this regard, the genre is also a successor of sorts to the former encyclopaedia, which at the time of Wikipedia seems to run out of fashion (some quarters resist bravely). Who among the present generation of students and researchers does not follow the sirens of GAFA facilities when taking first news about a particular topic, or keyword, she or he wants to learn about? How many students of religion are still trained the stamina and willing to include a decent library search or archival study in order to 'properly' research their topic beyond digital facilities?

${ }^{3}$ The OUP website advertises ca. 1280 titles, a third of which are paperbacks of previous hardcover publications. See https:// global.oup.com/academic/content/series/o/oxford-handbooks-ohbk/?cc=ch\&lang=en (last consulted 8.7.2020).

${ }^{4}$ Alongside some rather brief presentations (e.g., C. Travis Webb, Reading Religion, 16/11/2017 http://readingreligion.org/ books/oxford-handbook-study-religion; Mark S. M. Scott, Religious Studies Review 44:2 [2018], 209) I have noted
} 
chapters and contributors; (2) present some rather random observations using different critical lenses (macro, meso, micro); (3) compare this handbook to some of its elder cousins; and (4) discuss whether and how OHSR might have an effect on shaping the Study of Religion $\backslash$ s in terms of an academic discipline.

\section{(1) Contents and contributors}

Talking people, the assemblage of contributors obviously reflects part of the two editors' wide professional network. The resulting community includes 32 colleagues from ${ }^{5}$ Europe (Germany 11, UK 8, Denmark and Switzerland 3 each), 18 from North America (4 with Latin American pedigree or second affiliation; US 14, Canada 4), 2 each from Australia and New Zealand, 2 from South Africa, but none (as far as I can see) from Eastern Europe and Asia. Should we take this to be representative of the discipline and its (global) state of the art? Undoubtedly not (see Stausberg's ch. 50 for that matter), but a poll among present-day practitioners would probably have brought up quite a few among those here chosen by the editors. No less disconcerting is the fact that only seven out of 56 contributors are women $(12.5 \%$, considerably worse than the average leaky pipeline among scholars in the discipline), ${ }^{6}$ or that seniors outweigh juniors by far. But let me stress that when pointing to such unbalance I don't want to blame the editors, who have done a remarkable job by bringing together just such an impressive band of scholars, non-representative as it may be.

Contentwise OHSR appears reasonably balanced, more broadly conceived than previous handbooks (see below, sect. 3) and at times surprisingly innovative, a few conservative chapters rehearsing established (not to say outdated) wisdom notwithstanding. In terms of subject matter, there are of course the usual suspects (e.g. Hermeneutics, Marxism, and Social Theory), some of which included by the editors because they are 'not yet dead' (2), but one also encounters important keywords of relatively recent conjuncture (e.g., Religion \& Spirituality, Sports, and Tourism), some of which will in due course generate handbooks of their one. I welcome the explicit concern with 'Disintegration and Death of Religions' (ch. 43) as much as some critical reflections about the 'Relevance' (ch. 51) of the study of religion. A few chapter headings seem slightly redundant (e.g. 'Economics' \& 'Economy'; 'Materiality' and 'Objectification \& Commodification'). Other chapters could have benefitted from closer interaction between contributors (e.g., 'Hermeneutics' \& 'Semantics'; 'Semiotics' \& 'Communication'; 'Performance' \& 'Time'), laudable editorial attempts at cross-referencing notwithstanding. But I shall not engage here in quibbling over this or that omission, not always due to the editors' choice. ${ }^{8}$ The underlying question is of course whether a certain topic should be considered general, cross-culturally applicable and pertinent enough to generate the perceived need for systematic treatment in a handbook of this kind and ambition. The absence in chapter headings of many a keyword one might have wished to see is attenuated by a very

substantial discussions by Carlson (2017), Eduardo Rodrigues da Cruz (2017), both singling out her and his favourite chapters, and Schilbrack (2018) who addresses yet another edited handbook (King 2017), published after OHSR but with a narrower and slightly polemical concern.

${ }^{5}$ Contributors are counted according to their institutional affiliation, not origin.

${ }^{6}$ Carlson $(2017,1157)$ mentions 'a number of significant female scholars [ ... ] omitted at obvious junctures'. Note that King (2017) does only slightly improve on this matter (eight out of 44 contributors, $18.2 \%)$.

${ }^{7}$ See page 3 .

${ }^{8}$ Some omissions deserve to be mentioned though (e.g., aesthetics and sensory studies of religion, categorization, comparison, competition, embodiment, fiction, history, identity, representation, sacralization, stratification, universalism, or origins) Pace the editors' own assessment (3), apparent omissions are not any more conspicuous in Part $\mathrm{V}$ than elsewhere. Carlson $(2017,1157)$ particularly misses a chapter on race. 
detailed subject index (821-862). ${ }^{9}$ I should also point out that OHSR can be profitably used alongside the other handbook produced some years ago by the same editors, on research methods in the study of religion $\mid s .{ }^{10}$ The latter is more practically-minded, whereas OHSR provides building-blocks for a theory of the Study of Religion $\backslash$ s as an academic discipline. By conceiving the two volumes alongside each other (not to mention further commitments as a team), Engler and Stausberg have done a huge service to the discipline they advocate (see below, sect. 4).

\section{(2) Reading and using OHSR}

The two editors have strived to organize OHSR 'more coherently and systematically' than other works of a similar kind (1). They have first done so by defining seven distinct parts, some of whose superscripts reflect a real effort to use critically reflexive terminology: Part III 'Modes' is meant to address 'forms of the expression of religion' (2), a not very helpful characterization in my view for the actual topics discussed in that section, though. Part IV 'Environments' is a more apt denominator of the various 'social systems', arenas, culture-scapes or ecotopes discussed. Part VI 'Processes' is meant to stress the historicity of religion $\backslash$; it includes a chapter on objectification which might as well have figured in Part III, where David Morgan's chapter on 'Materiality' covers similar ground somewhat differently. All things considered, OHSR reaches a good degree of coherence without imposing an all too Procrustean grid. Formal coherence and pedagogical usefulness are enhanced by the inclusion of a summary, a glossary, substantial bibliographies and a selection of further readings in every single chapter. ${ }^{11}$ The summaries allow for quick orientation for the reader to evaluate the chapters' content. A few of them appear to lack sophistication, ${ }^{12}$ while others amount to a list of seemingly disconnected propositions; but most summaries are well-drafted and to the point. The dense summary for the first chapter 'Definition' is a fine example as it uses virtually all relevant concepts and distinctions: 'extension/intension', 'empirical/conceptual', 'lexicalism/objectualism', 'monotheic/polythetic'. As an effective summary, it registers expectable dilemmas before pointing to a productive (and pragmatic) resolution ('homeostatic property cluster definitions').

As important as the summaries are in practical terms, many a chapter discloses significantly more than what the summary makes you expect. Contributions are particularly helpful and appropriate to the handbook format when providing well-structured orientation, reporting and classifying relevant variations in the scholarly treatment of a certain topic, balancing arguments, strengths and weaknesses of different positions held rather than narrowly aiming to

\footnotetext{
${ }^{9}$ But note pp. 62-63 on how theories of religion condition (or frame) conceptions of 'origins of religion'. Unfortunately the subject index lacks the lemma 'origins'.

${ }^{10}$ Equally noted by Rodrigues da Cruz $(2017,223)$. A few chapters address the same or closely related topics in both volumes. Thus, Stausberg and Engler (2011) include chapters on feminist methodologies, hermeneutics, material culture analysis, spatial methods, and visual culture analysis. In one exceptional instance (semiotics), the same author was commissioned twice for the same topic.

${ }^{11}$ Academic practitioners will be grateful to the editors for having preferred chapter bibliographies to a huge cumulative bibliography at the end of the volume. Rodrigues da Cruz $(2017,224)$ rightly notes that the bibliography is dominated by English titles (after all, this is a handbook in English). Stausberg and other German contributors provide ample references to secondary literature in German; but references to research in French, Italian, or other Romance languages are rare, while non-European languages are virtually absent.

${ }^{12}$ E.g., an overly apologetic phrasing by Giovanni Casadio whose chapter aims 'to justify the general application of the taxon 'religion' as a unitary analytical concept situated in history, and to locate religions as interculturally translatable and communicable systems of beliefs and practices related to superhuman agents' (33), which seems to confuse the concept (or taxon) and its referents and overestimates the general translatability of 'systems', which is unwarranted precisely on historical grounds; or Gavin Flood's statement that 'Hermeneutics is the act of interpretation' (150) and not (as I would contend) a theory thereof.
} 
bring home an author's own perspective, ${ }^{13}$ and opens perspectives towards future research. ${ }^{14}$ The presentation of 'Cognitive Science' (ch. 6, by Armin W. Geertz), which succinctly distinguishes five significant new directions in CSR, namely neuropsychology, experimental science of religion, field experiments, history, and big data, is a model in this regard. The only reservation I might have is that the author could have devoted a paragraph or two to the limitations of CSR, whether perceived by its critics or due to the theoretical frame as such, inevitably reductionist (which in itself is no fault).

This is not the place to review chapters one by one, so I will focus on attempts to make new sense of much-criticized concepts, such as 'Belief, 'Experience', 'Gods', or 'Syncretism'. I found most of them both challenging and stimulating, especially when they seriously engage with criticism instead of bypassing it (as it happens in ch. 2 on 'Religion'). In the chapter on 'Belief (ch. 33), for example, Jason C. Bivins acknowledges that belief s 'contents' are often quite fuzzy, and he takes the criticism raised by Talal Asad and many others fully into account. Suggesting that we should relate the notion of 'belief to what is known as the 'lived religion', that is a strictly anthropological, approach, he exemplifies three different 'traditions' or ways of valuing belief through New Age religion, a Tamil Hindu festival in Kuala Lumpur, and a Catholic festival in Brooklyn. Stressing belief s entanglements with materiality, the senses and embodiment, and the political, are indeed interesting ways of circumventing the often-lamented pitfalls of Protestant bias in the debate on 'belief. As someone who teaches religion non-confessionally myself, but in the neighbourhood of Protestant theological discourse (from biblical through Reformation studies to systematic theology), I find myself constantly deconstructing the concept while also trying to explain the role it plays in Protestant discourse and discipline; as an intellectual and social historian, I thus like the idea put forward by Bivins that

'belief is an archive of disciplinary change, establishing a record around a category which continues to enshrine the very things the field abjures, its enduring power partly sustained by its centrality to the public acrimony fueling cultural interest in religion as such. (506)

The chapter on 'Social Theory' (ch. 16) is actually a discussion of how the category of the 'sacred' has been framed by classics such as Durkheim and Weber. This impulse allows chapter-authors Philip A. Mellor and Chris Shilling to analytically distinguish four competing modalities, two of which (the transcendent and the socio-religious sacred) they classify as religious, two others (the bio-economic and the bio-political) as non-religious. These four are then exemplified through Pentecostalism, the Islamic umma, modern 'fetishism of commodities', and Agamben's homo sacer. I find this typology thought-provoking and thus heuristically helpful, although I would not necessarily classify the latter two as non-religious. The views on spirituality of the authors of this chapter might be profitably related, and contrasted, to that of Heinz Streib and Constantin Klein, who in their chapter on 'religion and spirituality' (ch. 4) discuss the latter term as one of the most prominent contemporary competitors (in Western societies, at least) for 'religion'. That you may, as a researcher and/or an academic teacher, bring into conversation with each other chapters that have not been necessarily written for such a purpose adds value to a handbook like OHSR.

Any critical reader will inevitably stumble over a number of particular statements or positions held that he or she might find contestable-luckily so, in my view, unless handbooks

\footnotetext{
${ }^{13}$ As an example for the latter, I would not share David Morgan's enthusiasm for Maurice Merleau-Ponty's phenomenology as a particularly appropriate clue to the critical study of material religion, since the French philosopher's somewhat 'mystifying' language risks to throw back students of religion to a phase in the discipline's history that should by now be allowed to rest in peace. While I welcome the inclusion of Actor-network theory in the discussion, this needs to be carefully balanced against the risk, once again, to attribute agency to external instances in terms that come close to religious language itself.

${ }^{14}$ Carlson $(2017,1155)$ has a similar characterization for particularly successful treatments.
} 
were meant to be boring. Why, for instance, should Postcolonialism and postcolonial theory only be concerned with European imperialism (Arvind Mandair, p. 177)? It is a historical fact that it developed in response to the latter, which is probably one reason why it has become so fashionable especially in the US; but postcolonialism has long been adopted in Latin America to also scrutinize and criticize its exploitation by North American imperialism, and the entanglement of Southern with Northern American elites. There is ample postcolonial discourse on the history of slavery, in which non-European powers and traders were involved for centuries, not least legitimized by their respective religious experts and doctrines. Unfortunately, the lemma 'slavery' is absent from the subject index, just as 'subaltern', omissions hardly redeemed by a single mention of 'cargo cults' on 733. In contrast, 'universals', 'universality' (but not 'universalism') are concepts fairly spread throughout $O H S R$; but I cannot spot a single page where someone would reflect about connections between empire and universalism (including religious universalism), a relationship widely addressed in the study of empires ancient to modern.

Objections like the foregoing will be raised by any reader as he or she browses through this handbook. Knowing the editors, one may suspect that they themselves objected to some of their colleagues' bolder statements but did not want to exercise censorship against them, which in the final benefits all readers, from student to critic.

\section{(3) OHSR and previous companions}

Engler and Stausberg explicitly situate OHSR as a follow-up to similar 21st-century handbooks and companions, starting their genealogy with Willi Braun and Russell T. McCutcheon's Guide to the Study of Religion (2000, henceforth: GSR). It's nice to see them mention a few representatives of the genre published in languages other than English (although German and Portuguese can hardly represent all that remains). Comparing OHSR to its Anglo-American predecessors supports in some ways, but not in others OSHR's claim to be more coherent and systematic than its cousins: The sheer size and number of chapters, each of which discusses a really important issue in the study of religion Is exceeds that of former companions, and the newcomer can of course rely on and refer to far more up-to-date bibliography. This said, OHSR does not simply replace earlier handbooks which remain valuable today, not just as stations on the way of disciplinary self-reflections but also due to their sometimes different emphasis, which at times I find no less well-taken, especially when looking at GSR. Braun's chapter on 'Religion', presented as a prologue in $G S R$, announces coherence of a different kind, but coherence no less: their guide starts from describing practices in the study of religion/s, turns to explaining (or redescribing) them in terms of theory before critically reflecting on various locations of scholarship. In terms of content, some of the keywords I mentioned above as missing from OHSR are well developed in GSR (e.g., classification [J. Z. Smith], comparison [Luther H. Martin], origin [Tomoko Masuzawa], or stratification [Gustavo Benavides]), which will thus remain on the shelf as an important signpost both to embrace the discipline and to assess OHSR in terms of ongoing debates and changing priorities.

The situation differs slightly with Hinnells' (2005) and Segal's (2006) companion volumes, ${ }^{15}$ which viewed from a distance have more of a 'Religious Studies' touch, thus including chapters on theology, phenomenology, philosophy of religion, or religious studies for that matter, but also anthropology, economics, psychology, or sociology of religion, approaches or (sub-)disciplines which Engler and Stausberg chose not to address in specific chapters (to the exception of economics, which makes the latter's double representation in OHSR all the more

\footnotetext{
${ }^{15}$ See Uehlinger (2006) for a comparative review of the two.
} 
conspicuous). 'Religious Studies' is the explicit referent of Robert A. Orsi's companion published in 2012, a colourful and contrasting potpourri of epistemological, theoretical, and methodological variations, e.g., on 'Sympathy, Suspicion, and Studying religion' (L. E. Schmidt), 'Thinking about Religion, Belief, and Politics' (T. Asad), or 'Special Things as Building Blocks of Religions' (Ann Taves). The book offers lots of critical insights and opinions, some more predictable than others; but it hardly manages-nor actually attempts, to be fair - to delimitate a peculiar discipline strictly speaking. In this respect, OHSR stands in closer continuity to GSR than to the latter three companions.

Interestingly enough (and ironically perhaps), Braun and McCutcheon's guidebook has recently got a massive successor of sorts with Richard King's Religion, Theory, Critique (King 2017) that appeared a few months after OHSR and, we are told, after roughly a decade of difficult gestation. As mentioned earlier, the two books have been compared by Schilbrack (2018), who characterizes OHSR as based on fundamentally 'realist' assumptions regarding the Study of Religion\s' object of study, in contrast to King's collection which focuses on the critical deconstruction of discursive practices construing 'religion' and its study. Schilbrack rightly considers that 'these two books do not represent two tribes in the academic study of religion' $(2018,455)$, not least perhaps because they share more than a handful contributing colleagues (most notably among them, Steven Engler himself). But since Stausberg has recently published a rather harsh review of King's collection, which he calls 'neither a handbook nor a textbook' $(2019,97)$, the divide is serious and should not be taken lightly.

\section{(4) OHSR and the Study of Religion $\backslash$ s as a discipline}

OHSR is not a book about Religious Studies. ${ }^{16}$ This handbook is intended to sharpen the profile of the Study of Religion as a self-standing discipline in its own right, whose contours are critical and whose and complexity is demanding enough not to engage in too much neighbouring business of different kind. It is for this very reason that the editors chose not to include chapters on theology and religion-related subsets of other disciplines such as anthropology, philosophy, psychology, or sociology, just as OHSR has no chapters on specific religions or religious traditions and their academic study. I can think of many good arguments to support this stance, especially as Stausberg (in ch. 50; building on Engler and Stausberg 2011) resumes the discipline's history as one of increasing institutional consolidation throughout the 20th century, an expanding outreach beyond Western Europe, North America and Japan since the 1960s, 'in the context of a worldwide expansion of tertiary education' (775), but also an 'ongoing marginality' (792) both institutionally and in terms of numbers of professional practitioners, among which there are 'few generalists' (795). This raises the question whether institutionalisation has so far advanced as to allow for ongoing differentiation and a sufficient number of colleagues within a Study of Religion $\backslash$ s department to cover as wide a field as marked out by OHSR without recourse to interdisciplinary 'Religious Studies' cooperation. Does the latter endanger the discipline's coherence or can it contribute to a better dissemination of understanding beyond the discipline's innermost circles for what it can achieve and contribute to academia and society at large? Should we approach the problem pragmatically and empirically, or dogmatically and theoretically?

Engler and Stausberg are realistic enough to understand that the discipline's status in the future will depend on its capacity to make itself understood by a wider audience, among

\footnotetext{
${ }^{16}$ Religious studies as a field $[\ldots]$ is a relatively amorphous area of academic work that covers all sorts of studies of religious phenomena undertaken by scholars from a variety of academic disciplines, whereas the study of religion $\backslash s$ as a discipline addresses one institutionally distinct segment of this field (775-776).
} 
which university boards, funding agencies and their reviewers (who are often not peers from the discipline), but also public and private institutions, media professionals and the wider public. The final chapter (51) 'Relevance' by Thomas A. Tweed, a professor of American Studies and History at Notre Dame and also the author of a 'theory of religion' (2006) is an invitation to unbox our inhibitions and 'intellectual mediocrity' (Stausberg, 793) and to think of the Study of Religion $\backslash s$ as an attractive discipline. Starting from the question: 'Why study religion?', Tweed offers some very good arguments in defense of the value of humanities at large, focusing these on studying religion, among which the cultivation of empathy, tolerance, and openness (following Hinnells 2005, 9, 15) but also a capacity of broadening narrow sectarian visions: 'That broadening begins with respectful and responsible comparison' (808). At the risk of appearing as a spoilsport, however, Tweed's question was not: 'Why study the Study of Religion \s?' His answers thus may encourage practitioners who find themselves in larger coalitions (be it of Religious Studies programs) but they will only help those ready to let go some of the more sterile internal frictions and any kind of touchiness, who are willing and able to truly demonstrate what kinds of 'added value' a non-confessional study of religion $\backslash$ s can offer society at large in more than a single context and for a variety of purposes. Are we ready to accept the challenge?

As any academic discipline, the study of religion/s needs lively and, at times, polemical debates, and they should be about something more substantial than 'religion scholars disagree among themselves about what constitutes the "academic" study of religion' (806). At the time of writing (in January 2020), members of the IAHR had been informed that as the organization prepared for its XXII ${ }^{\text {nd }}$ Quinquennial World Congress to be held in Otago, New Zealand, 'its Executive Committee will recommend to the Otago International Committee that the IAHR change its name from the International Association for the History of Religions (IAHR) to the International Association for the Study of Religions (IASR)', a proposal which seeks to steer midway between the current name and the more audacious proposal to go for the Science of Religion. ${ }^{17}$ The handbook here reviewed seems well prepared to outlive this name change should it ultimately occur, but the guild might be well advised to think more seriously about the place it wants to save, in its future development, for what it is called to drop and leave behind (namely, history whose status in the study of religionls has long been unclear) and for what it seems reluctant to accommodate in earnest (science, which of course conjures up something else today than what it meant to Friedrich Max Müller).

\section{References}

Braun, Willi, and Russell T. McCutcheon. 2000. Guide to the Study of Religion. London - New York: Cassell.

Carlson, Liane F. 2017. "Review of OHSR." Journal of the American Academy of Religion 85 (4): 1155-1157. doi:10.1093/jaarel/lfx053.

Engler, Steve, and Michael Stausberg. 2011. "Introductory Essay: Crisis and Creativity: Opportunities and Threats in the Global Study of Religion\s.” Religion 41 (2): 127-143. doi:10.1080/0048721X.2011.591209.

Fujiwara, Satoko, and Tim Jensen. 2020. "What's in a (Change of) Name? Much - But Not That Much - and Not What Wiebe Claims." Method and Theory in the Study of Religion 32 (2): 159-184. doi:10.1163/ 15700682-12341478.

Hinnells, John, ed. The Routledge Companion to the Study of Religion. London - New York: Routledge.

King, Richard, ed. 2017. Religion - Theory - Critique: Classic and Contemporary Approaches and Methodologies. New York: Columbia University Press.

Orsi, Robert A. 2012. The Cambridge Companion to Religious Studies (Cambridge Companions to Religion). Cambridge - New York: Cambridge University Press.

\footnotetext{
${ }^{17}$ Proofreading in July 2020 allows me to refer interested readers to a recent issue of Method and Theory in the Study of Religion (Wiebe 2020 vs. Fujiwara and Jensen 2020).
} 
Rodrigues da Cruz, Eduardo. 2017. "Review of OHSR.” Revista de Estudos da Religião (REVER) 17 (1): $224-230$. doi:10.23925/1677-1222.2017vol17ila11.

Schilbrack, Kevin. 2018. "What Does the Study of Religion Study?" Harvard Theological Review 111 (3): 451458. doi:10.1017/S0017816018000196.

Segal, Robert A., ed. 2006. The Blackwell Companion to the Study of Religion (Blackwell Companions to Religion). Malden, MA - Oxford - Carlton, VI: Blackwell Publishing.

Stausberg, Michael, and Steve Engler., eds. 2011. The Routledge Handbook of Research Methods in the Study of Religion. London - New York: Routledge.

Stausberg, Michael. 2019. “Review of King 2017.” Numen 67 (1): 95-98. doi:10.1163/15685276-12341563.

Tweed, Thomas A. 2006. Crossing and Dwelling: A Theory of Religion. Cambridge, MA: Harvard University Press.

Uehlinger, Christoph. 2006. ““Interested Companionship: A Review Article” [on Hinnells 2005 and Segal 2006].” Numen 53 (3): 359-384. doi:10.1163/156852706778544979.

Wiebe, Don. 2020. "A Report on the Special Executive Committee Meeting of the International Association for the History of Religions in Delphi." Method and Theory in the Study of Religion 32 (2): 150-158. doi:10.1163/ 15700682-12341477.

Christoph Uehlinger

Department of Religious Studies, University of Zurich, Zurich, Switzerland (2) christoph.uehlinger@uzh.ch (1) http://orcid.org/0000-0002-0511-6315

(C) 2020 Christoph Uehlinger https://doi.org/10.1080/0048721X.2020.1796421 